\title{
Physico-Chemical Properties of Three Salt-Affected Soils in the Lower Volta Basin and Management Strategies for their Sustainable Utilization
}

\author{
D. F. K. Allotey ${ }^{*}$, R. D. Asiamah², C. D. Dedzoe ${ }^{2}$ and A. L. Nyamekye ${ }^{1}$ \\ ${ }^{1}$ CSIR-Soil Research Institute, Accra Centre, P. O. Box M. 32, Accra, Ghana \\ ${ }^{2}$ CSIR-Soil Research Institute, Academy Post Office, Kwadaso-Kumasi, Ghana \\ *Corresponding author; E-mail: dfkallotey@yahoo.comor soilri@ncs.com.gh
}

\begin{abstract}
Differences in physical and chemical properties of three salt-affected soils, designated as pedons 1, 2 and 3, in the Lower Volta basin of Ghana were evaluated. Pedons 1 and 2 were located at Mokordzie in the South Tongu District while Pedon 3 was at Salo in the Ketu District of the Volta Region of Ghana. The soil properties determined included texture, $p \mathrm{H}$, organic carbon, available $\mathrm{P}$ and $\mathrm{K}$, exchangeable bases and acidity. The texture of the soils varied from clay to silty clay. The low $p \mathrm{H}$ of the soils, attributed to the presence of pyrite, ranged from moderately acidic to extremely acidic and vary in the order Pedon $1>$ Pedon $3>$ Pedon 2 . The electrical conductivity of all the three pedons were more than $4 \mathrm{dS} / \mathrm{m}$, thus, their rating as moderately saline. Organic $\mathrm{C}$ content in the A-horizon of pedons 1 and 2 were comparatively higher than Pedon 3. Total N contents of the three pedons was generally low. Available K, on the other hand, was very low within all the horizons of Pedon 2; medium in Pedon 3 and ranged from very low to medium in Pedon 1. The CEC of the A-horizon of Pedon 1 is medium but the B-horizon is between low to high. Those of pedons 2 and 3 were between medium to very high in both horizons. The CEC is generally in the decreasing order Pedon $1>$ Pedon $2>$ Pedon 3. Exchangeable sodium percentage (ESP) of all the three pedons were lower than 15, hence, the soils were rated saline. Based upon these data, pedons 1, 2, and 3 were classified as Gleyic Solonetz, Endogypsi-Gleyic Solonchak and Gleyic Solonchak, respectively. Suggested management practices to improve upon the productivity of these soils are ridges/mounds, application of lime (gypsum or oyster shells), organic manures and residues, planting of salt-tolerant crops, agroforestry, leaching and drainage.
\end{abstract}

\section{Introduction}

Excess sodium on the soil exchange complex and/or soluble salts in the soil profile has rendered an estimated 318,000 ha of cropland in Ghana marginally unproductive (FAO, 1988). Salt-affected soils, as they are called, are either saline or sodic. Saline soils refer to soils with electrical conductivity above $4 \mathrm{dS} / \mathrm{m}$ and usually contain sufficient soluble salts that adversely affect the growth of most crops. The soluble salts are mainly chlorides and sulphates of sodium, calcium and magnesium. Sodic soils refer to soils with exchangeable sodium percentage above 15 , with sodium salts capable of alkaline hydrolysis and are mainly $\mathrm{Na}_{2} \mathrm{CO}_{3}$. These two main groups of salt-affected soils differ (physically, chemically, biologically, as well as their geographical and geochemical distribution) and, therefore, require different approaches for their reclamation and agricultural utilization. Although these two groups of soils account for very large proportion of salt-affected soils worldwide, there are also transitional groups with intermediate properties. Common types under the transitional groups are acid-sulphate and degraded sodic soils.

An estimated 200,000 ha of salt-affected soils in Ghana are saline (FAO, 1988), with 36,790 ha located within the Lower Volta basin (Brammer, 1967; Asiamah, 1996). This saline condition is caused by the ingress of seawater and deposition of salty water particles carried by wind from the Atlantic Ocean. This has probably aggravated the breakdown in the natural cycle of soil leaching and drying due to poor rainfall and reduction of fresh water supply to the basin as a result of the construction of the Akosombo and Kpong dams (Amatekpor, 1989, 1995). With the exception of the narrow sand bars at Anloga, cultivated to shallots, crop cultivation on these soils are limited due to their saline nature. The saline nature of the soils has not only affected the income generating ability of the inhabitants but also their standard of living.

Recognizing the paucity of research data on these salt-affected soils in the country, the study was conducted with the objectives of 1) determining the physical, chemical and morphological characteristics of the selected saltaffected soils at selected sites, 2) classifying the soils under the Ghanaian (Brammer, 1956, 1962) and World Reference Base for soil resources classification systems (ISSS/ISRIC/FAO, 1998), 3) examining their major constraints on crop production, and 4) suggesting some management practices to improve upon their productivity.

Study area

\section{Materials and methods}

West African Journal of Applied Ecology, Vol. 12, 2008 
The study sites are located between longitudes $0^{\circ} 29^{\prime} 54^{\prime \prime}$ and $1^{\circ} 4^{\prime} 47^{\prime \prime}$ E and latitudes $5^{\circ} 44^{\prime} 51^{\prime \prime}$ and 6 $6^{\circ} 47^{\prime \prime} \mathrm{N}$ within the South Tongu and Ketu districts of the Volta Region (Fig. 1). Generally, fishing and farming are the main occupations of the people in the area. Maize, pepper and cassava are the main crops cultivated. Geologically, the area is underlain by Dahomeyan rocks, which are believed to be Pre-cambrian in age and form bands of acidic and basic gneiss (Junner \& Bates, 1945). According to Tamakloe (1966), the Dahomeyan is overlain mainly by Pleistocene to recent formations of mud, clays and gravel. Towards the sea, beach sands are more abundant. Clay containing crystals of gypsum and soluble salts are mostly found in lagoon areas.

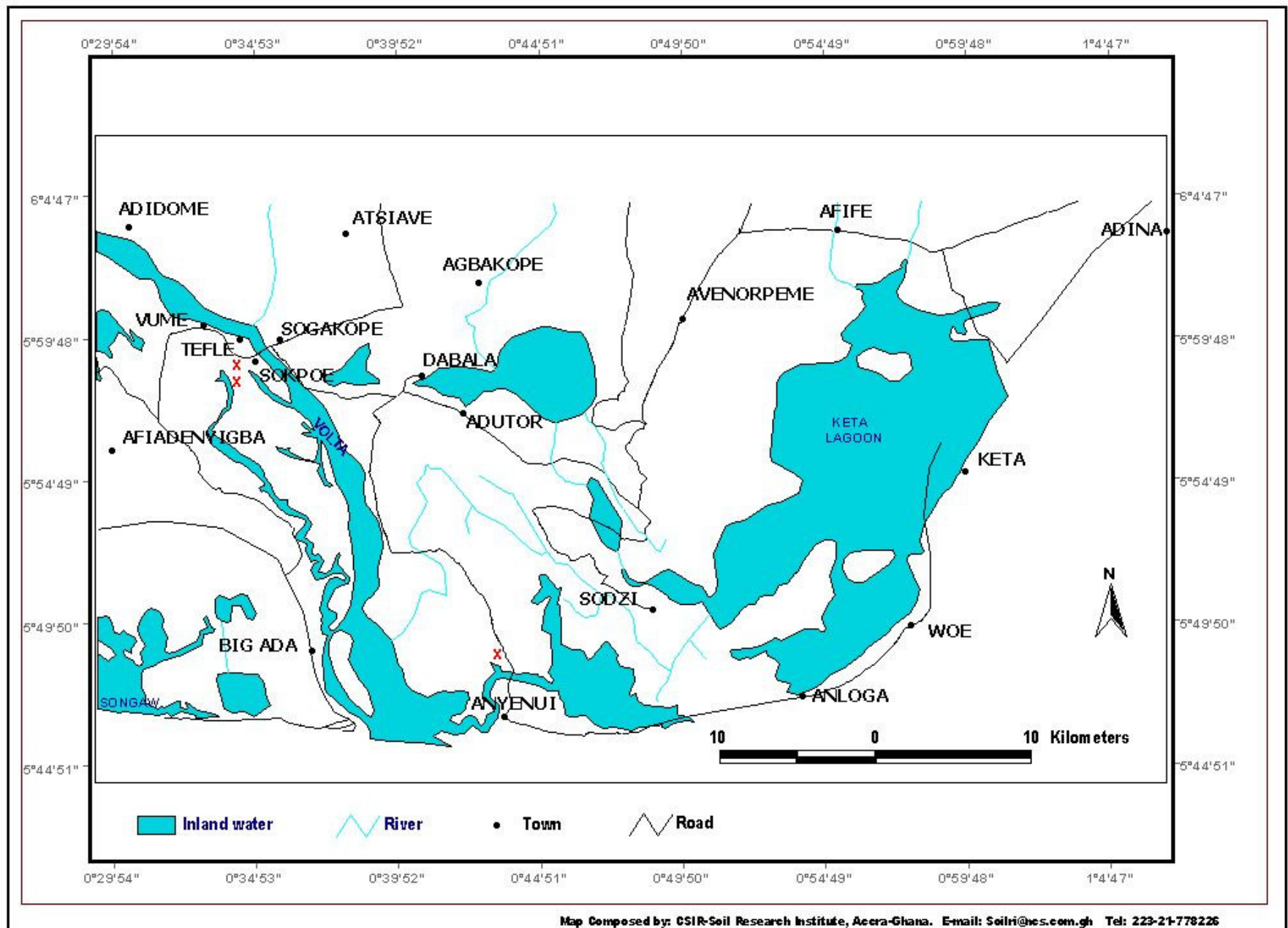

Fig 1: Location of the three pedons (marked " $x "$ ) within the Lower volta Basin of Ghana

The climate in the study area is semi-arid tropical with average daily temperatures ranging $27-28{ }^{\circ} \mathrm{C}$ with no pronounced variation during the year. The winds of this part of coastal West Africa are generally weak and regular with predominant southeasterly winds which become South-West Monsoon upon crossing the Equator (Arfi et al., 1993). The monthly average wind speed is between 1.7 and $2.6 \mathrm{~ms}^{-1}$. During the harmattan season (DecemberFebruary), the dominant winds blow from the northeast (N-E Trades). The NE Trades and SW monsoons create a seasonal pattern of rainfall with the main rainy season starting from April to July and the minor season in September-October. This part of the country is one of the driest with a mean annual rainfall of $783 \mathrm{~mm}$ at Keta and a mean annual evaporation of $1964 \mathrm{~mm}$. The usual tropical rains of squally nature accompanied by thunder are almost absent in this area (Tamakloe, 1966), making it different from many tropical regions. The relative humidity in the area is generally more than $90 \%$ during the night and decreases to as low as $65 \%$ early in the morning with a seasonal variation of $15 \%$. Periods of very low humidity occur during the harmattan. 
The study sites are within the coastal savanna zone of Ghana. The climatic conditions only support the growth of tropical grassland. Small and scattered clumps of short trees and shrubs can also be found at the fringes of lagoons and rivers in the area (Anonymous, 1998). These fringes are occupied mainly by mangroves (Rhizophora racemosa), isolated patches of grasses (especially, Paspalum sp.) and herbs (Sesuvium portulacastrum). Cyperus articulatus and cat-tail (Typha domin-gensis) are sedges commonly found in the less brackish parts of the lagoons in the area.

\section{Field investigations}

Three salt-affected sites (Table 1) were selected within the Lower Volta basin using previous soil survey reports of the area as a guide (Brammer, 1962; Asiamah, 1984, 1995). Two pedons were selected at Mokordzie and AgaveAfedume both in the South Tongu District and one at Salo in the Ketu District of the Volta Region. These were designated as Pedon 1, 2 and 3, respectively. Profile pits were dug down to the water table at each selected site and the soils described according to the Guidelines for Soil Profile description (FAO, 1990). Each pedon was sampled horizon by horizon for physical and chemical analyses in the laboratory.

TABLE 1

Soil salinity rating based on electrical conductivity

Soil salinity class

Non saline

Slightly saline

Moderately saline

Strongly saline

Very strongly saline
$E C(d S / m)$

$0-2$

$2-4$

$4-8$

$8-16$

$>16$

Source: FAO Soil Bull. 39 (1988).

TABLE 2

Physical and chemical properties of the three salt-affected pedons

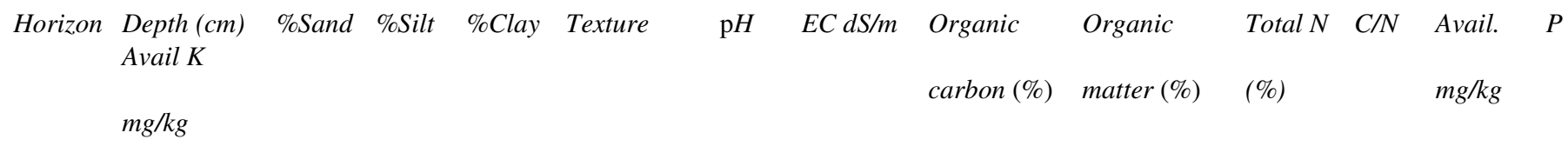

Pedon 1 (Mokordzie)

\begin{tabular}{|c|c|c|c|c|c|c|c|c|c|c|c|c|c|}
\hline Ap & 0 & 3.2 & 46.4 & 50.4 & Silty-clay & 5.1 & 4.1 & 2.9 & 5.1 & 0.06 & 49.0 & 19.5 & 184.0 \\
\hline Acp & $2-$ & 50.3 & 30.9 & 68.8 & Clay & 4.4 & 4.7 & 1.5 & 2.5 & 0.08 & 18.5 & 4.9 & 128.8 \\
\hline $\mathrm{Cg} 1$ & $5-$ & 50.5 & 20.5 & 79.0 & Clay & 4.8 & 5.0 & 1.0 & 1.7 & 0.11 & 8.7 & 4.2 & 55.2 \\
\hline $\mathrm{Cg} 2$ & 45 & 12.7 & 42.2 & 55.1 & Clay & 5.6 & 4.6 & 0.2 & 0.4 & 0.04 & 5.5 & 3.5 & 41.4 \\
\hline $2 \mathrm{Cg} 1$ & $71-$ & 71.7 & 49.2 & 49.1 & Silty-clay & 7.0 & 4.4 & 0.3 & 0.6 & 0.11 & 3.1 & 3.5 & 64.4 \\
\hline $2 \mathrm{Cg} 2$ & $97-$ & 309.4 & 47.3 & 43.4 & Silty-clay & 6.2 & 4.4 & 0.3 & 0.5 & 0.03 & 10.3 & 4.2 & 239.2 \\
\hline $2 \mathrm{Cg} 3$ & 130 & 3610.0 & 46.0 & 44.0 & Silty-clay & 6.5 & 5.0 & 0.6 & 1.0 & 0.03 & 20.3 & 2.1 & 50.6 \\
\hline \multicolumn{14}{|c|}{ Pedon 2 (Agave-Afedome) } \\
\hline Ap & $0-10$ & 7.0 & 42.9 & 50.1 & Silty-clay & 5.0 & 4.4 & 2.7 & 4.6 & 0.13 & 21.3 & 7.7 & 78.2 \\
\hline Acp & $10-28$ & 6.3 & 44.9 & 48.8 & Silty-clay & 4.5 & 5.9 & 1.5 & 2.6 & 0.08 & 18.2 & 3.5 & 46.0 \\
\hline $2 \mathrm{Cg} 1$ & $28-61$ & 8.9 & 26.3 & 64.8 & Clay & 4.5 & 4.7 & 0.8 & 1.3 & 0.08 & 9.0 & 2.1 & 82.8 \\
\hline $2 \mathrm{Cg} 2$ & $61-92$ & 0.3 & 34.1 & 65.7 & Clay & 4.6 & 4.7 & 0.5 & 0.9 & 0.06 & 8.1 & 3.5 & 33.1 \\
\hline $2 \mathrm{Cgc} 1$ & $92-114$ & 1.3 & 26.3 & 72.4 & Clay & 5.0 & 4.5 & 0.3 & 0.4 & 0.05 & 5.3 & 2.8 & 33.1 \\
\hline $2 \mathrm{Cgc} 2$ & $114->150$ & 1.8 & 27.7 & 70.5 & Clay & 4.4 & 4.9 & 0.2 & 0.4 & 0.06 & 4.1 & 4.2 & 33.6 \\
\hline \multicolumn{14}{|c|}{ Pedon 3 (Salo) } \\
\hline Apg & $0-10$ & 1.7 & 59.6 & 38.7 & Silty-clay & 4.5 & 6.4 & 0.8 & 1.3 & 0.08 & 9.5 & 11.2 & 289.8 \\
\hline $\mathrm{ACgc}$ & $10-31$ & 0.9 & 51.2 & 47.9 & Silty-clay & 4.4 & 5.1 & 1.0 & 1.7 & 0.04 & 24.3 & 3.5 & 276.0 \\
\hline $2 \mathrm{Cgc} 1$ & $31-53$ & 1.2 & 53.3 & 45.6 & Clay & 4.9 & 4.4 & 0.2 & 0.4 & 0.05 & 4.4 & 4.2 & 193.2 \\
\hline
\end{tabular}




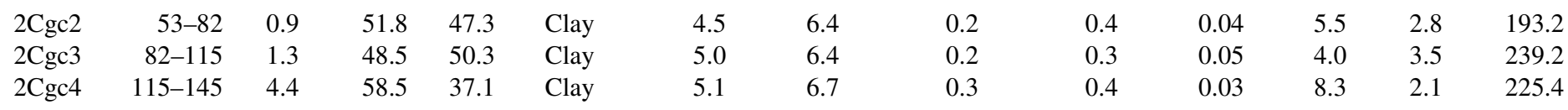

TABLE 2 cont.

\begin{tabular}{|c|c|c|c|c|c|c|c|c|c|c|c|c|c|c|c|c|}
\hline \multirow[t]{2}{*}{ Horizon } & \multirow[t]{2}{*}{ Depth $(\mathrm{cm})$} & \multirow[b]{2}{*}{$K$} & \multicolumn{2}{|c|}{$\begin{array}{l}\text { Exchan. bases } \\
\mathrm{cmol}(+) / \mathrm{kg}\end{array}$} & \multirow[b]{2}{*}{$M g$} & \multirow[t]{2}{*}{$\begin{array}{l}\text { Total exch. } \\
\text { bases }\end{array}$} & \multirow{2}{*}{$\begin{array}{l}\text { Exch. } \\
\text { acidity } \\
(A l+H)\end{array}$} & \multirow{2}{*}{$\begin{array}{l}\text { C.E.C } \\
\text { cmol } \\
(+) / k g\end{array}$} & \multirow[t]{2}{*}{$\% B S$} & \multirow[t]{2}{*}{$E S P \%$} & \multirow[t]{2}{*}{$\begin{array}{c}(\mathrm{Ca}+\mathrm{Na}) / \\
T E B\end{array}$} & \multicolumn{5}{|c|}{$\%$ Saturation } \\
\hline & & & $\mathrm{Na}$ & $\mathrm{Ca}$ & & & & & & & & $K$ & $\mathrm{Na}$ & $\mathrm{Ca}$ & $M g$ & \\
\hline \multicolumn{17}{|c|}{ Pedon 1 (Mokordzie) } \\
\hline Ap & $0-2$ & 0.9 & 2.5 & 4.2 & 0.4 & 8.0 & 0.3 & 23.0 & 96.7 & 11.0 & 83.8 & 4.0 & 11.0 & 18.2 & 1.6 & 1.1 \\
\hline Acp & $2-25$ & 0.6 & 3.8 & 5.6 & 0.4 & 10.4 & 1.2 & 29.8 & 89.5 & 12.8 & 90.2 & 2.1 & 12.8 & 18.8 & 1.3 & 4.1 \\
\hline $\mathrm{Cg} 1$ & $25-45$ & 0.4 & 2.9 & 5.5 & 0.4 & 9.2 & 1.4 & 22.1 & 87.0 & 12.9 & 91.1 & 2.0 & 12.9 & 25.1 & 1.7 & 6.3 \\
\hline $\mathrm{Cg} 2$ & $45-71$ & 0.4 & 5.0 & 4.2 & 0.4 & 9.9 & 0.2 & 44.5 & 97.6 & 11.2 & 92.5 & 0.9 & 11.2 & 9.3 & 0.8 & 0.5 \\
\hline $2 \mathrm{Cg} 1$ & $71-97$ & 0.4 & 5.6 & 4.8 & 0.4 & 11.1 & 0.2 & 41.0 & 98.5 & 13.7 & 93.1 & 1.0 & 13.7 & 11.6 & 0.9 & 0.4 \\
\hline $2 \mathrm{Cg} 2$ & $97-130$ & 0.6 & 0.7 & 3.5 & 0.2 & 5.1 & 0.2 & 20.6 & 95.9 & 3.5 & 83.6 & 3.0 & 3.5 & 17.0 & 1.1 & 1.0 \\
\hline $2 \mathrm{Cg} 3$ & $130-136$ & 0.4 & 2.1 & 3.8 & 0.3 & 6.6 & 0.3 & 15.5 & 95.7 & 13.7 & 89.9 & 2.3 & 13.7 & 24.6 & 2.1 & 1.9 \\
\hline
\end{tabular}

Pedon 2 (Agave-Afedome)

\begin{tabular}{|c|c|c|c|c|c|c|c|c|c|c|c|c|c|c|c|c|}
\hline Ap & $0-10$ & 0.5 & 1.0 & 4.0 & 0.3 & 5.8 & 1.5 & 27.4 & 79.1 & 3.6 & 86.1 & 1.8 & 3.6 & 14.8 & 1.2 & 5.6 \\
\hline Acp & $10-28$ & 0.3 & 2.5 & 4.4 & 0.3 & 7.6 & 3.2 & 20.8 & 70.5 & 12.2 & 91.6 & 1.5 & 12.2 & 21.3 & 1.6 & 15.3 \\
\hline $2 \mathrm{Cg} 1$ & $28-61$ & 0.3 & 4.8 & 4.0 & 0.3 & 9.5 & 3.2 & 44.0 & 74.8 & 10.9 & 93.2 & 0.7 & 10.9 & 9.2 & 0.8 & 7.3 \\
\hline $2 \mathrm{Cg} 2$ & $61-92$ & 0.3 & 5.0 & 4.8 & 0.3 & 10.4 & 2.7 & 43.0 & 79.5 & 11.6 & 94.5 & 0.6 & 11.6 & 11.2 & 0.7 & 6.2 \\
\hline $2 \mathrm{Cgc1}$ & $92-114$ & 0.3 & 2.5 & 5.3 & 0.4 & 8.4 & 1.9 & 40.3 & 81.9 & 6.1 & 92.3 & 0.7 & 6.1 & 13.2 & 0.9 & 4.6 \\
\hline $2 \mathrm{Cgc} 2$ & $114->150$ & 0.3 & 2.1 & 5.0 & 0.4 & 7.7 & 1.5 & 29.2 & 83.8 & 7.3 & 91.5 & 1.1 & 7.3 & 17.0 & 1.2 & 5.1 \\
\hline
\end{tabular}

Pedon 3 (Salo)

\begin{tabular}{|c|c|c|c|c|c|c|c|c|c|c|c|c|c|c|c|c|}
\hline Apg & $0-10$ & 1.2 & 6.0 & 3.1 & 0.4 & 10.6 & 0.2 & 47.6 & 98.2 & 12.5 & 85.5 & 2.5 & 12.5 & 6.5 & 0.8 & 0.4 \\
\hline $\mathrm{ACgc}$ & $10-31$ & 1.1 & 3.1 & 4.6 & 0.4 & 9.2 & 0.2 & 29.4 & 97.9 & 10.5 & 83.8 & 3.8 & 10.5 & 15.7 & 1.2 & 0.7 \\
\hline $2 \mathrm{Cgc} 1$ & $31-53$ & 1.2 & 2.3 & 4.0 & 0.4 & 7.9 & 0.2 & 28.1 & 97.0 & 8.1 & 80.5 & 4.2 & 8.1 & 14.4 & 1.2 & 0.9 \\
\hline $2 \mathrm{Cgc} 2$ & $53-82$ & 1.9 & 4.6 & 4.5 & 0.4 & 11.4 & 0.4 & 42.1 & 96.5 & 10.9 & 79.9 & 4.5 & 10.9 & 10.7 & 0.9 & 1.0 \\
\hline $2 \mathrm{Cgc} 3$ & $82-115$ & 2.0 & 4.9 & 5.2 & 0.4 & 12.5 & 0.3 & 42.8 & 97.3 & 11.4 & 80.8 & 4.7 & 11.4 & 12.1 & 0.9 & 0.8 \\
\hline $2 \mathrm{Cgc} 4$ & $>115$ & 1.8 & 4.7 & 3.6 & 0.3 & 10.5 & 0.2 & 40.7 & 97.8 & 11.6 & 79.6 & 4.4 & 11.6 & 8.8 & 0.8 & 0.6 \\
\hline
\end{tabular}

\section{Laboratory methods}

Particle size analysis was done by the pipette method as described by Gee \& Bauder (1986). Soil reaction $(p \mathrm{H})$ and electrical conductivity (EC) were measured in 1:1 soil : water suspension. Total nitrogen in the samples was determined by the modified Kjeldahl method (Bremner, 1996). Available phosphorus and potassium contents in the soils were extracted by Bray's $\mathrm{P}_{1}$ solution and measured on a spectrophotomer and flame photometer, respectively (Bray \& Kurtz, 1945). Organic carbon was determined by the wet oxidation method of Walkley \& Black (1934). Exchangeable bases were extracted with $1.0 \mathrm{M}$ ammonium acetate solution at $p \mathrm{H}$ 7.0. Sodium and potassium contents in the extract were determined by flame photometry while calcium and magnesium contents were obtained by atomic absorption spectrophoto-metry. Thomas (1982) method was used for the determination of exchangeable acidity. Cation exchange capacity (CEC) was determined using the ammonium distillation method. Total exchangeable bases and percent base saturation were then calculated using values obtained from the exchangeable bases and exchangeable acidity. Exchange-able sodium percentage (ESP) was calcula-ted by using the equation below:

$$
\mathrm{ESP}=(\text { Exchangeable Na/CEC }) \times 100
$$


Soil classification was based on the Ghanaian (Brammer, 1956, 1962) and World Reference Base Soil Classification System (ISSS/ISRIC/FAO, 1998).

\section{Morphology, characterization and classi-fication}

\section{Results and discussion}

Pedon 1 is a poorly-drained saline soil developed on alluvial deposits. The first three horizons are very dark gray (10 yr 3/1) while the lower horizons are light gray (2.5 yr 7/2) (Table 3). This soil is often flooded during the wet season, but the water table drops to about $1.4 \mathrm{~m}$ from the surface during the dry season. This is shown by strong brown (7.5 yr 5/6) and brownish yellow (10 yr 6/8) mottles throughout the profile. The subsoil is a humus-stained silty clay to clay (Table 3 ) with soft and hard iron and manganese concretions. Pedon 1 was, therefore, classified as Oyibi and Gleyic Solonetz according to the Ghanaian (Brammer, 1956, 1962) and the World Reference Base Soil Classification System (ISSS/ISRIC/FAO, 1998), respectively.

\begin{tabular}{|c|c|c|c|c|c|c|c|c|c|}
\hline \multirow[b]{2}{*}{ Pedon } & \multicolumn{9}{|c|}{$\begin{array}{r}\text { TABLE } 3 \\
\text { Field description of selected salt-affected }\end{array}$} \\
\hline & Horizon & $\begin{array}{l}\text { Depth } \\
(\mathrm{cm})\end{array}$ & Colour & Texture & Structure & $\begin{array}{l}\text { Consist- } \\
\text { ence }\end{array}$ & Roots & Boundary & Special features \\
\hline $\begin{array}{l}1 \\
\text { dry, fine } \\
\text { present, }\end{array}$ & Ap & $0-2$ & $10 \mathrm{yr} 3 / 1$ & stcl & $3 \mathrm{mgr}$ & stph & Common fine medium & Diffuse smooth & $\begin{array}{l}\text { Hard surface crust, vertical cracks } \\
\text { interstitial and channel pores } \\
\text { reddish yellow mottles. }\end{array}$ \\
\hline $\begin{array}{l}\text { dry, } \\
\text { present, }\end{array}$ & $\mathrm{Cg} 1$ & $25-45$ & $10 \mathrm{yr} 3 / 1$ & $\mathrm{c}$ & co & stph & Abundant very fine & Diffuse smooth & $\begin{array}{l}\text { Strong brown mottles, vertical cracks } \\
\text { fine interstitial and channel pores } \\
\text { iron and manganese concretions. }\end{array}$ \\
\hline $\begin{array}{l}\text { cracks } \\
\text { pores } \\
\text { concretio }\end{array}$ & $\begin{array}{l}2 \mathrm{Cgc} 1 \\
\text { ons. }\end{array}$ & $71-97$ & $2.5 \mathrm{yr} 7 / 2$ & stcl & $4 \mathrm{fi}$ & stph & Few very fine roots & Abrupt smooth & $\begin{array}{l}\text { Brownish yellow mottles, vertical } \\
\text { dry, fine interstitial and channel } \\
\text { present, iron and manganese }\end{array}$ \\
\hline mottles. & $2 \mathrm{Cgc} 2$ & $97-130$ & $2.5 \mathrm{yr} 7 / 2$ & stcl & 4 & stp & Few very fine roots & Abrupt smooth & Borwnish yellow and strong brown \\
\hline & $2 \mathrm{Cgc} 3$ & $130-160$ & $2.5 \mathrm{yr} 7 / 2$ & stcl & 4 & stp & & & \\
\hline
\end{tabular}

Texture: $\quad$ c: clay, cl: clay loam, l: loam, scl: sandy clay loam, sl: sandy loam, sicl: silty clay loam, sil: silty loam, ls: loamy sand, s: sand, st: silt. Structure: $\quad 0$ : structureless, 1: weak, 2: moderate, 3: strong, 4: massive, f: fine, m: medium, gr: granular, abk: angular block, sbk: subangular blocky, co: columnar, stk: sticky, p: plastic, h: hard, fi: firm, cs: coarse.

TABLE 3 cont.

\begin{tabular}{|c|c|c|c|c|c|c|c|c|c|}
\hline Pedon & Horizon & $\begin{array}{l}\text { Depth } \\
(\mathrm{cm})\end{array}$ & Colour & Texture & Structure & $\begin{array}{l}\text { Consist } \\
\text { ence }\end{array}$ & Roots & Boundary & Special features \\
\hline 3 & Apg & $0-10$ & $10 \mathrm{yr} 4 / 2$ & $\mathrm{cl}$ & 3 mcsfi & stp & Many fine roots & Diffuse smooth & $\begin{array}{r}\text { Hard surface crust, brownish yellow } \\
\text { mottles, hard spherical }\end{array}$ \\
\hline
\end{tabular}




\section{ACgc $\quad 10-31 \quad 2.5 \mathrm{yr} 4 / 2 \quad \mathrm{cl} \quad 3$ messbk $\quad$ stp $\quad$ Many fine roots}

manganese

concretions.

$$
\text { 2Cgc1 31-53 } 5 \text { yr 6/2 cl } 4 \mathrm{fi} \quad \text { stp } \quad \text { Common very fine root }
$$

and iron

$$
\text { 2Cgc2 } 53-82 \quad 5 \mathrm{yr} 5 / 2 \quad \mathrm{cl} \quad 4 \mathrm{fi} \quad \text { stp } \quad \text { Few very fine roots }
$$

hard

and iron concretions.
Diffuse smooth

Dark grayish brown mottles, spherical soft and hard and iron

Diffuse smooth Yellowish brown mottles, spherical soft and hard manganese concretions.

Diffuse smooth Yellowish brown mottles, spherical and irregular soft and manganese

2Cgc3 $\quad 82-115 \quad 5$ yr 6/1 $\quad$ cl $\quad 4$ fi $\quad$ stp $\quad$ Very few fine roots $\quad$ Clear smooth

hard

and iron concretions.

$2 \mathrm{Cgc4} \quad 115-145 \quad 5 \mathrm{yr} 4 / 1 \quad$ sil $\quad 4$ fi $\quad$ stp $\quad$ Very few, very fine roots

medium,

spherical and irregular soft and hard

manganese and iron concretions.

Texture: $\quad$ c: clay, cl: clay loam, l: loam, scl: sandy clay loam, sl: sandy loam, sicl: silty clay loam, sil: silty loam, ls: loamy sand, s: sand, st: silt.

Structure: $\quad 0$ : structureless, 1: weak, 2: moderate, 3: strong, 4: massive, f: fine, m: medium, gr: granular, abk: angular block, sbk: subangular blocky, co: columnar, stk: sticky, p: plastic, h: hard, fi: firm, cs: coarse.

\begin{tabular}{|c|c|c|c|c|c|c|c|c|c|}
\hline Pedon & Horizon & $\begin{array}{l}\text { Depth } \\
\text { (cm) }\end{array}$ & Colour & Texture & Structure & $\begin{array}{l}\text { Consist- } \\
\text { ence }\end{array}$ & Roots & Boundary & Special features \\
\hline $\begin{array}{l}2 \\
\text { interstiti } \\
\text { pores pre }\end{array}$ & $\begin{array}{l}\text { Ap } \\
\text { al } \\
\text { esent. }\end{array}$ & $0-10$ & $10 \mathrm{yr} 3 / 1$ & stcl & fi & stp & Many very fine roots & Diffuse smooth & $\begin{array}{r}\text { Hard surface crust, many fine } \\
\text { and channel }\end{array}$ \\
\hline common & $\begin{array}{l}\text { Acp } \\
\text { fine }\end{array}$ & $10-28$ & $10 \mathrm{yr} 3 / 2$ & stcl & 3 msbkfi & stp & Many very fine roots & Diffuse smooth & $\begin{array}{r}\text { Many fine channel pores present. } \\
\text { Yellowish red mottles, } \\
\text { channel pores. }\end{array}$ \\
\hline $\begin{array}{l}\text { channel } \\
\text { gypsum }\end{array}$ & $\begin{array}{l}2 \mathrm{Cg} 1 \\
\text { crystals. }\end{array}$ & $28-61$ & $10 \mathrm{yr} 3 / 2$ & $\mathrm{cl}$ & 3 msbkfi & stp & Common fine roots & Clear smooth & $\begin{array}{c}\text { Red mottles, many very fine } \\
\text { pores, irregular hard }\end{array}$ \\
\hline $\begin{array}{l}\text { channel } \\
\text { gypsum }\end{array}$ & $\begin{array}{l}2 \mathrm{Cg} 2 \\
\text { crystals, so } \\
\text { manganes }\end{array}$ & $\begin{array}{l}61-92 \\
\mathrm{ft}\end{array}$ & $10 \mathrm{yr} 4 / 1$ & $\mathrm{cl}$ & $4 \mathrm{fi}$ & stp & Many fine roots & Diffuse smooth & $\begin{array}{c}\text { Red mottles, many very fine } \\
\text { pores, irregular hard }\end{array}$ \\
\hline $\begin{array}{l}\text { brown } \\
\text { and iron }\end{array}$ & $2 \mathrm{Cgc} 1$ & $92-114$ & $2.5 \mathrm{yr} 5 / 2$ & $\mathrm{cl}$ & $4 \mathrm{fi}$ & stp & $\begin{array}{l}\text { Common very fine } \\
\text { root }\end{array}$ & Clear smooth & $\begin{array}{l}\text { Strong brown and dark yellowish } \\
\text { mottles, soft manganese } \\
\text { concretions. }\end{array}$ \\
\hline & $2 \mathrm{Cgc} 2$ & $114-150$ & 2.5 yr $6 / 1$ & $\mathrm{cl}$ & $4 \mathrm{fi}$ & stp & & & \\
\hline
\end{tabular}

TABLE 3 cont.

Texture: $\quad$ c: clay, cl: clay loam, l: loam, scl: sandy clay loam, sl: sandy loam, sicl: silty clay loam, sil: silty loam, ls: loamy sand, s: sand, st:silt.

Structure: $\quad$ : structureless, 1: weak, 2: moderate, 3: strong, 4: massive, f: fine, m: medium, gr: granular, abk: angular block, sbk: subangular blocky, co: columnar, stk: sticky, p: plastic, h: hard, fi: firm, cs: coarse. 
Pedon 2 is also imperfectly drained, compact and saline. The surface horizon is very dark gray silty loam to silty clay loam (Table 3). The surface horizons are made up of heavy clay, which is very dark gray to grayish brown in colour with yellowish brown and reddish brown mottles (Table 3). Gypsum crystals are found below the depth of 61 $\mathrm{cm}$ in the profile. Based upon the above information, Pedon 2 was, therefore, classified as Ada series (Brammer, 1956, 1962) and Endogypsi-Gleyic Solonchak under the Ghanaian and the World Reference Base Soil Classification System (ISSS/ISRIC/FAO, 1998), respectively.

Pedon 3 is compact, saline and developed within a floodplain. Both the topsoil and subsoil of this pedon (Table 3 ) are mottled brownish yellow (10 yr 6/8), yellowish brown (10 yr 6/8) and dark red (2.5 $\mathrm{yr} 4 / 6)$. The soil is poorly-drained and becomes flooded during the wet season. The water table drops to about $1.5 \mathrm{~m}$ from the surface during the dry season. The soil is deep and has heavy clay topsoils. The lower horizons are heavy-textured but silty loam textures may also be encountered with increasing depths (Table 3). Manganese concretions can be found throughout the profile. Pedon 3 was, therefore, classified as Muni series and Gleyic Solonchak under the Ghanaian (Brammer, 1956, 1962) and the World Reference Base Soil Classification System (ISSS/ISRIC/FAO, 1998), respectively.

\section{Physical and chemical properties}

Soil physical properties. Particle size distribution and colour of the three pedons are presented in Tables 2 and 3. The soils have silty-clay textures within a few centimeters of their topsoil while the subsoil has mainly clay textures. The sand content decreases with corresponding increase in clay content with depth in all the three pedons. Pedons 2 and 3 have about $30 \mathrm{~cm}$ silty-clay topsoil layer which is underlain by clay to depths of more than $140 \mathrm{~cm}$. Pedon 1 , on the other hand, has a variable textured pattern below the silty-clay layer. These textures include clay and siltyclay layers. This may reflect different depositional regimes.

\section{Chemical properties}

Soil $\mathrm{pH}$. Vertical distribution of soil $\mathrm{pH}$ values was characterized by an erratic trend from the top to bottom horizons (Table 2), perhaps coinciding with different depositional regimes of the soil parent material. Soil reaction in Pedon 1 is acidic in the A-horizon (Siderius, 1992) but slightly acidic to neutral in the B-horizon. Soil reaction in Pedon 2 ranged from 4.4 to 5.0 (very strong acid). Pedon 3 is extremely acid to strong acid (4.4-5.1). The $p \mathrm{H}$ decreased with increasing depths in all the A-horizons of all the three pedons but increased with increasing depths within the B-horizon. The low $p \mathrm{H}$ levels observed in these soils are attributable to the presence of pyrites (Asiamah; personal communication). Pyrites upon oxidation and hydration generally produce hydrogen sulphide which hydrolyses into sulphuric acid to reduce the soil $p \mathrm{H}$.

The resulting $p \mathrm{H}$ of the soil after drainage and drying depends on the amount of pyrite oxidized and the amount of acid neutralizing components such as silicates, carbonates and exchangeable bases in the soil (Hechanva, 2004). Pre-dam construction data show $p \mathrm{H}$ of soils within the lower Volta basin to be moderately acid (Brammer,1967). However, results obtained from this study show that soil $p \mathrm{H}$ is declining toward very strongly acid levels. These results corroborate the findings of other studies (MacDonald et. al., 1987; Amatekpor, 1989) which show a rapid decline in soil $p \mathrm{H}$ in the basin after the construction of the two hydroelectric dams in the country. The low $p \mathrm{H}$ level observed in the three pedons is due to the pyrite content of these soils, which, upon exposure, results in gradual oxidation (especially the sulphur fraction) into sulphuric acid. Decreasing soil reaction may result in the deficiencies of potassium, phosphorus, molybdenum, sulphur and zinc (Munns \& Franco, 1982).

\section{Electrical conductivity}

High concentrations of soluble salts are also detrimental to plant growth. Soils are rated based on their degree of salinity (Table 1).Whereas increasing trends in EC with increasing depths were observed in the A-horizons of pedons 1 and 3, decrement with increasing depths in Pedon 3 was observed. The C-horizon, on the other hand, showed increasing trends in EC with increasing depths of pedons 2 and 3 but erratic trend in Pedon 1. Electrical conductivity (EC) of all the three pedons is more than $4 \mathrm{dS} / \mathrm{m}$ but less than $8 \mathrm{dS} / \mathrm{m}$. They are, therefore, moderately saline. Pedon 3 had the highest EC values (4.4-6.7 dS/m) and Pedon 1 the lowest $(4.1-5.0 \mathrm{dS} / \mathrm{m})$. The higher EC 
values observed in Pedon 3 may be due to the proximity of this site to the Keta lagoon and other smaller lagoons as well as salty-water particles deposited from the wind.

\section{Organic carbon, nitrogen, available phosphorus and potassium status}

Soil organic carbon is a key resource owing to its ameliorative effect on nutrient supply, detoxification of harmful soil constituents, moisture and nutrient retention and its role in soil structure formation. Organic carbon content (Table 2) in the A-horizon of Pedon 1 and Pedon 2 are medium (1.5\%) to high (2.9\%), but low (0.8\%$1.0 \%$ ) in Pedon 3 (Siderius, 1992). Decrements in organic carbon were observed with increasing depths in the Ahorizon of pedons 1and 2 but increment with increasing depths in Pedon 3. Contents in the B- and C- horizons showed an increment with increasing depths. The C-horizon is low in organic carbon in all the three pedons. However, increasing trends in organic carbon with increasing depths could be found in the C-horizon of pedons 1 and 3 but decrements with depths in Pedon 2. The high organic carbon content of pedons 1 and 2 could be attributed to crop residue additions from previous cropping, whereas the very low levels of Pedon 3 may be due to the grassland vegetation of the area. The low organic carbon levels in the C- horizons of all three pedons (about $0.2 \%$ ) indicate the fluventic nature of the pedons.

Total nitrogen content (Table 2) is generally very low in the A- and B- horizons of all the three pedons (Siderius, 1992). This indicates low $\mathrm{N}$ releases from the organic matter sources, since nitrogen content of soils is usually positively, correlated with organic matter content, since over $90 \%$ of the nitrogen found in soils is in organic form (Brady, 1990). Furthermore, the carbon to nitrogen ratio (C:N) of the A-horizon of the three soils, especially Ap and $\mathrm{ACp}$ is generally outside and higher than the common range of 8:1-15:1 for arable soils as proposed by Brady (1990).

Available phosphorus content (Table 2) in Pedon 1 was high in the Ap horizon but low in the ACp horizon. However, it was low throughout the B-horizons. Levels in Pedon 2 were medium in Ap but low in the Acp horizons. Low available P levels were observed in all layers of the C-horizon. Similar trends were also observed in Pedon 3 as in Pedon 2. There is generally a decreasing trend in available $\mathrm{P}$ with increasing depths in all the three pedons. The low organic matter content coupled with the highly acidic conditions of these soils may explain the low available-P levels in the soils (Munns \& Franco, 1982). Application of phosphatic fertilizers, such as single or triple super phosphate may, therefore, be necessary to boost crop production on these soils. However, the type and rate will depend on the crop to be cultivated and other environmental factors.

Available K levels are medium in both Ap and Acp horizons of Pedon 1 (Table 2) but low throughout the entire A- and C-horizons of Pedon 2. Pedon 3, on the other hand, is high in the A-horizon but medium in the C-horizon. The low levels of available $\mathrm{K}$ observed are attributable to the low organic matter levels and $p \mathrm{H}$ of these three pedons (Munns \& Franco, 1982). Potassium fertilizer applications may be necessary for good crop yields in these soils.

\section{Exchangeable cations and acidity}

In all horizons, Pedon 3 had the highest levels of exchangeable cations and acidity (Table 2). Decreasing trends with increasing depths were observed in the A-horizon of all the three pedons. Erratic trends with increasing depths was observed in the C-horizon of pedons 1 and 2 but that of Pedon 3 increased from 1.2 to $2.0 \mathrm{cmol}(+) / \mathrm{kg}$. Within all comparable depths, exchangeable sodium content was highest in Pedon 3 (Table 2). The Na content in Pedon 1 was slightly greater than in Pedon 2 at 0-97 cm. Below these depths, the Na concentration in Pedon 1 was lower than that of Pedon 2. With the exception of Pedon 3, all other pedons showed an increment in exchangeable Na with increasing depths. However, the Apg layer of Pedon 3 contained the highest exchangeable $\mathrm{K}(6.0 \mathrm{cmolm}(+) / \mathrm{kg}$. The high exchangeable Na content of Pedon 3 could be attributed to the nearness of the pedon to the sea and cluster of lagoons in the area. The high Na content in the Apg of Pedon 3, on the other hand, could partly be explained by crystallized salt deposition observed on its surface.

Exchangeable Ca content is compara-tively the highest among the exchangeable bases in the three pedons (Table 2). Apart from similarity in the levels of $\mathrm{K}$ and $\mathrm{Mg}$ in Pedon 2, exchangeable bases within the similar generic horizons in the three pedons were in the order $\mathrm{Ca}>\mathrm{Na}>\mathrm{K}>\mathrm{Mg}$. Increments of exchangeable Ca with increasing depths were found in the A-horizons of all the three pedons. With regards to the C-horizon, increments in 
exchangeable $\mathrm{Ca}$ with increasing depths were observed in all pedons except Pedon 1. Exchangeable $\mathrm{Ca}$ and $\mathrm{Na}$ accounted for more than $79 \%$ of cations at the exchange site of all the three pedons. The comparatively higher calcium content of these pedons supports the findings of Asiamah (1984) that calcium is progressing in these soils. With such high calcium levels, the $p \mathrm{H}$ of soils is expected to be high but owing to the presence of pyrite the $p \mathrm{H}$ levels are rather low. Furthermore, the high sodium levels observed in these pedons may be attributed to enrichment from ingressed seawater and deposition by salty water particles carried by the wind (FAO, 1988) due to the basin's proximity to the Atlantic Ocean.

Exchangeable $\mathrm{Mg}$ levels were very low in all the horizons of the three pedons (Table 2). Constant levels of exchangeable $\mathrm{Mg}$ were observed within the A-horizons of the three pedons with increasing depths. Levels in the Chorizon, generally, decreased with increasing depths in pedons 1 and 3 but increased slightly with increasing depths in Pedon 2.

\section{Exchangeable acidity and aluminium saturation}

Exchangeable acidity was generally low in both A- and C-horizons of the three pedons but comparatively highest in Pedon 2 and least in Pedon 3. The trend in exchangeable acidity in the three soils was in the order Pedon $2>$ Pedon 1 > Pedon 3 (Table 2). Aluminium saturation percentage was very low in all the three pedons. Furthermore, increments and decrements with increasing depths were observed in the A- and C-horizons, respectively, in all the three pedons. Soils can change when there is rapid change in their environment, which also influences their surface chemistry (Schofield, 1949; Nikiforroff, 1953; Cline, 1961). Exchangeable acidity is caused almost completely by aluminium ions (Coleman \& Thomas, 1967). The hydroxyl-Al and hydroxyl-Fe coatings on layer silicates are proton donors responsible for much of the $p \mathrm{H}$-dependent charge of soils. Kamprath (1967) noted that $p \mathrm{H} \mathrm{4.5-5.8} \mathrm{in}$ mineral soils indicates that sufficient exchangeable $\mathrm{Al}$ is present to reduce plant growth. If exchangeable $\mathrm{Al}$ occupies more than $60 \%$ of the CEC, toxic levels of aluminium in soils will result (Nye et al., 1961).

In the ionic state, $\mathrm{Al}$ is toxic to plant roots because it hinders cell division. The fertility of acidified soils is restricted by enrichment of $\mathrm{Al}$ and $\mathrm{Mn}$ and increased proportions of $\mathrm{H}$-ions in soil solution and on colloidal surfaces at the expense of basic cations. Simultaneously, the propensity of soil minerals to weather is increased. Weather-ing, therefore, leads to release of both basic and acidic ions, which have buffering effects and prevent a rapid reduction in $p \mathrm{H}$. Gyori et al. (1985) showed that reductions in maize yields were more closely correlated with $\mathrm{Al}$ saturation than with soil $p \mathrm{H}$. Since the percent Al saturation of the three pedons are far below $60 \%$, Al toxicity was not expected to occur in these soils. This also buttresses the fact that the low $p \mathrm{H}$ observed in the three soils is due to the presence of pyrite and not aluminium ions.

\section{Percent cation saturation}

The percent K saturation of the A- horizon of the three pedons ranged from 2.1 to 4.0, 1.5 to 1.8 and 2.9 to 3.8 for pedons 1, 2 and 3, respectively. Furthermore, they all decreased from the top most layer (Ap and Apg) to those below (Acp and $\mathrm{ACgc}$ ). The C-horizon ranged from 0.9 to 3.0, 0.6 to 1.1 and 3.8 to 4.7 in pedons 1, 2 and 3, respectively. Percent Na saturation increased from the Ap horizon to Acp in all the pedons except Pedon 3. The Chorizon increased with increasing depths in pedons 1 and 3 with the reverse order in Pedon 2. Increases in percent calcium saturation with increasing depths were observed in all the A-horizons with increasing depths. Whereas percent calcium saturation in the C-horizon of Pedon 2 increased with increasing depths that of Pedon 3 decreased with Pedon 1 being erratic. Magnesium saturation of CEC generally increased with increasing depths in pedons 2 and 3 but decreased in Pedon 1. Increments from $0.8 \%$ to $2.1 \%$ and 0.8 to $1.2 \%$ were observed in the C-horizon of pedons 1 and 2, respectively, with decrements in Pedon $3(1.2-0.9 \%)$.

According to Bear \& Toth (1948), Graham (1959) and Eckert (1987), ideal percent saturation ranges for soils are 60-80, 10-25 and 3-5 for $\mathrm{Ca}, \mathrm{Mg}$ and $\mathrm{K}$, respectively. Furthermore, with regard to $\mathrm{Mg}$, its fertilization is recommended if the percent saturation drops below $15 \%$ or the ratio of $\mathrm{Mg}: \mathrm{K}$ is less than $2: 1$. With regard to $\mathrm{Mg}$, its fertilization is recommended if the percent saturation drops below $15 \%$ or the ratio of $\mathrm{Mg}: \mathrm{K}$ is less than 2:1. Soil values above these ranges indicate excessive levels while those below indicate deficiencies. Percent $\mathrm{K}, \mathrm{Ca}$ and $\mathrm{Mg}$ saturation levels in both the A- and C- horizons of all the three pedons are below the critical values of the above- 
mentioned range for potassium, calcium and magnesium. This indicates that external inputs in the form of fertilizers are necessary for higher and sustainable crop yields on them.

\section{Cation exchange capacity (CEC)}

The CEC is generally in the decreasing order Pedon $1>$ Pedon $2>$ Pedon 3 (Table 2). The CEC of the A-horizon of Pedon 1 was medium $(23.0-29.8 \mathrm{cmol}(+) / \mathrm{kg})$ but between low to medium $(15.5-44.5 \mathrm{cmol}(+) / \mathrm{kg})$ in the Chorizon. Increment in CEC with increasing depths was observed in this A-horizon of the pedon. On the other hand, cation exchange capacity in the A-horizon of both pedons 2 and 3 showed decrements with increasing depths. Furthermore, their C-horizons decreased and increased with increasing depths, respectively. Cation exchange capacity is a means of estimating soil fertility. Soils with high CEC values are considered fertile and vice versa. In general, CEC ranges from a minimum of $2 \mathrm{cmol}(+) \mathrm{kg}^{-1}$ soil in sands and up to a maximum of $60 \mathrm{cmol}^{(+)} \mathrm{kg}^{-1}$ in clay soils (Brady, 1990). The CEC of the three pedons are in the decreasing order of Pedon $1>$ Pedon $2>$ Pedon 3 (Table 2). This trend is consistent with the report by Thomas \& Swoboda (1963) that with rising $p H$ above 5.5, CEC generally increases. Furthermore, Schrofield (1949) also found that CEC of some clay soils was constant between $p \mathrm{H} 2.5$ and 5.0 but increased between $p \mathrm{H} 5.0$ and 7.0. This partly supports the increasing trends in $p \mathrm{H}$ and CEC with increasing depths as observed particularly in Pedon 1. Cation exchange capacity was only closely and negatively related with $p \mathrm{H}$ in Pedon $2(r=-0.6 ; \propto 0.05)$ but not with Pedon $1(r=0.01 ; \propto=0.05)$ and $3(r=-0.08$; $\propto=0.05)$. Furthermore, the CEC was significantly and negatively related to EC in all the three pedons (Pedon 1: $r=$ $-0.9 ; \propto=0.001$; Pedon 2: $r=-0.6 ; \propto=0.001$ and Pedon 3: $r=-0.8 ; \propto=0.05$ ) but weakly correlated with ESP in Pedons $1(r=-0.077 ; \propto=0.05)$ and $3(r=-0.002 ; \propto=0.05)$. However, it was positively and significantly correlated with ESP in Pedon $2(r=-0.7 ; \propto=0.05)$.

\section{Exchangeable sodium percentage (ESP)}

The ESP levels of the A- and C- horizons of the three pedons follow the trend Pedon $3>$ Pedon $1>$ Pedon 2 (Table 2). Exchangeable sodium percentage (ESP) in the A-horizon of all the three pedons except Pedon 3 showed increments with increasing depths. The C-horizon of pedons 1 and 3, however, showed EC increases with increasing depths while the reverse showed in Pedon 2. The ESP and EC of the three pedons were below 15 but more than $4 \mathrm{dS} / \mathrm{m}$, respectively. Salt-affected soils are rated according to the levels of their electrical conductivity and exchangeable sodium percentage as shown in Table 4. Hence the three pedons are saline. These results are in agreement with the findings of the earlier workers on these soils such as Brammer (1967) and Asiamah (1996).

\section{TABLE 4}

Salt affected soils rating based on electrical conductivity (EC) and exchangeable sodium percentage (ESP)

$\begin{array}{ll}E C \text { and ESP ranges } & \text { Rating } \\ \mathrm{EC}<4.0 \text { and } \mathrm{ESP}<15 & \text { Non-saline } \\ \mathrm{EC}>4.0 \text { and } \mathrm{ESP}<15 & \text { Saline } \\ \mathrm{EC}<4.0 \text { and } \mathrm{ESP}>15 & \text { Sodic } \\ \mathrm{EC}>4.0 \text { and } \mathrm{ESP}>15 & \text { Saline-sodic } \\ \text { U.S. Salinity Laboratory Staff, 1954. }\end{array}$

\section{Pedogenic process and classification}

Soil salinity may occur under irrigated and non-irrigated conditions (Anomynous, 2004). When salinity occurs under irrigated and non-irrigated conditions it is termed irrigated land salinity and 'dryland' salinity, respectively. Hence, the three pedons can be regarded as exhibiting dryland salinity since the annual rainfall of $783 \mathrm{~mm}$ at Keta, the nearest meteorological station to these sites, is very low. Furthermore, the three pedons lie mainly on old river terraces and alluvial lands within the lower Volta basin and are, therefore, developed from alluvial parent materials and lacustrine deposits.

Possible sources of salts in the soils have been identified as ocean drifts, underground water, deposition by wind and mineral weathering (Asiamah, 1995). The salty underground water at the sampling sites has influenced the 
morphology and chemistry of the soils. These are revealed especially in the high levels of $\mathrm{Na}$ and $\mathrm{Ca}$ throughout the soil profiles (Table 2). The $\mathrm{Na}$ and $\mathrm{Ca}$ ions account for between 83.8-93.1, 86.1-94.5 and 79.9-85.5\% of the exchangeable complex in pedon 1, 2 and 3, respectively. Abundant gypsum crystals were observed in the upper layer of the B-horizon of Pedon 2 (Table 3). This suggests that the soil is currently undergoing salinization (Asiamah, 1984). Furthermore, very high levels of exchangeable $\mathrm{Na}$ in the A- and C- horizons of Pedon 3, compared to the other two pedons, suggest that Pedon 3 has probably received more salts due to its proximity to the adjoining small lagoons in the area. The main sources of salts in the surface horizon of these soils are, therefore, from the salty groundwater of the nearby lagoons and wind deposits from the sea.

\section{Effect of salinity on soil properties}

Salinity affects soil physical properties by causing fine particles to bind together into aggregates. This process, known as flocculation, is beneficial in terms of soil aeration, root penetration and root growth. Excessively high salinity conditions are, however, detrimental to plant growth. High sodium concentrations in soil generally cause soil dispersion as a result of break down of soil aggregates, which, subsequently, settle into soil pores. Soil dispersion causes soil pore blockage resulting in the reduction of soil permeability. Three main problems caused by sodium-induced dispersion are reduced infiltration, reduced hydraulic conductivity and surface crusting (Frenkel et. al., 1978; van de Graaf \& Patterson, 2001; Pearson, 2004).

Surface crusting is a characteristic of sodium-affected soils (Frenkel et. al., 1978; van de Graaf and Patterson, 2001; Pearson, 2004). This phenomenon may account for the hardened upper layers or surface crust observed in these soils (Table 3). The hardened upper layers or surface crust are likely to restrict water infiltration and seed emergence. The primary causes of surface crusting are 1) physical dispersion caused by raindrops or irrigation water, and 2) chemical dispersion. Surface crusting due to rainfall is greatly enhanced by sodium induced clay dispersion (Morin et al., 1981). When clay particles disperse within soil water, the dispersed clay particles plug macropores in the soil surface, thereby, 1) blocking avenues for water and roots to move through the soil, and 2) soil structure is lost during dispersion and a cement-like surface layer is formed upon drying.

\section{Amelioration and management}

van Doren \& Triplett (1979) proposed that the method of soil management to be used in any particular area should have a beneficial effect on particular soil problems, as well as being suitable to crop, the prevailing climate and the socio-economic situation of the area. In this paper, the socio-economic constraints on full development of the salt-affected soils of the Lower Volta basin have not been comprehensively addressed. It is, however, important to note that these constraints are as serious as the technical constraints.

Technical feasibility of a soil management system for the Lower Volta basin could be evaluated in terms of how efficiently it deals with the physical, chemical and biological soil constraints under the prevailing climatic conditions. From the soil constraints already discussed, a technically feasible manage-ment system will have to satisfy all or most of the following interrelated requirements: (1) reduce salinity levels to the barest minimum, (2) increase internal drainage and water holding capacity, (3) enhance the overall fertility of soils for higher and sustainable crop yields, (4) increase soil structural stability and reduce surface sealing and crusting, and (5) decrease runoff and erosion.

Many techniques are in use world-wide to ameliorate salt-affected soils. These include application of chemicals (Srivastava \& Srivastava, 1994), organic manure (More, 1994), crop residues, leaching (Islam, 1993; Sharma \& Manchanda, 1996), ploughing and seed-bed preparation, agroforestry and breeding resistant varieties (Sun \& Dickinson, 1995). Inhabitants of these areas mostly depend on farming and fishing for their livelihood. Major management options are expensive and can only be undertaken by the Government or other funding agencies. However, simple techniques can be adopted by farmers to improve on their agricultural productivity. These include 1) use of ridges/mounds, 2) oyster shells, and 3) organic matter.

Raising of mounds or ridges with judicious use of organic matter (crop residue, manure, compost) will help improve both physical and chemical properties of the soil for better crop performance. Much of the salt would easily leach during the early rains with the organic matter improving both the physical and chemical conditions. Use of chemical fertilizers when available would also enhance soil productivity. Chemical amelioration could also be 
employed to improve the productivity of these soils. Oyster shells, a calcium-rich material source, abounds in soils a few kilometres upstream from these selected sites, as reported by Dogbetor et al. (1999). This material could be used not only as a cheap salinity ameliorant but also to reduce the acidity in these soils. However, the rate of application of powdered oyster shells would have to be determined in order to achieve sustainable high yields.

Introduction and selection of salt-tolerant crops. Economic crops tolerant to salinity could be tested and introduced into the area. Crops that show better perfor-mance should be selected for adoption. Rice production is considered to be satisfactory during the initial years of reclamation of such soils even though it is classified only as semi-tolerant (FAO, 1988) since it can withstand ponding and salts get diluted in soils under water-saturated conditions. After rice, legumes such as cowpea are recommended to build up the nitrogen budget of the soil through nitrogen fixation.

Agroforestry. Woody perennial species could be grown in association with annual row crops. This system attempts to promote the beneficial effects of bush fallowing while an annual crop is still being grown on the land. Important among this group is alley cropping where fast growing woody perennial legume species are planted in 4$10 \mathrm{~m}$-wide rows. Annual crops are then planted between these rows with prunings from the perennial species providing mulch, organic matter and nutrients to the soil for the benefit of the annual crop.

Leaching and drainage. Leaching and drainage are the two essential components of any permanent solution to salinity problem. Fresh water from the Volta river will be the best water source for leaching since it is of better quality and abounds within the basin all year round. However, economic factors such as the cost of pumping of fresh water to the selected site may be major limiting factors to the implementation of these techniques. In this regard, the need for governmental intervention cannot be overemphasized.

\section{Conclusion}

The study indicated that the three pedons (pedons 1,2 and 3) are saline since their EC and ESP are more than 4 $\mathrm{dS} / \mathrm{m}$ and less than 15, respectively. Pedon 3 has both the highest EC and ESP while Pedon 2 has the lowest levels. The three pedons were classified as Oyibi, Ada and Muni under the Ghanaian System of Classification and Gleyic Solonetz, Gleyic Solonchak and Endogypsi-Gleyic Solonchak, respectively, under the World Reference Base Systems of Classification. It is also apparent from the study that the soils are clayey and low in fertility due to their low N, available P and K. Leaching as well as applications of partially or completely processed oyster shells and organic manures, such as poultry manure and cow dung, would be necessary to reduce the salinity and improve the fertility status of the soils. However, their economic rates of application would have to be assessed to achieve sustainable crop yields. Raising of ridges or mounds would improve drainage and provide better conditions for plant growth. Periodic monitoring of salinity levels in the soil is vital in the management of these soils. Remote sensing and GIS techniques could be employed in monitoring the salinity levels in these soils.

\section{Acknowledgement}

The study could not have been carried out without the support of FAO and AgSSIP. Special thanks go to Messrs E. A. Akuffo, O. Mensah and all staff of the Analytical Service Division, CSIR-Soil Research Institute, Accra, for the analytical work done on the samples. The authors are also grateful to Messrs T. Ayamga, E. Agyei-Kwarteng, and Emmanuel Darteh for their support throughout the period. Finally, the authors express their gratitude to Mr E. A. Dennis and Dr. R. N. Issaka for their advice during the preparation of the manuscript.

\section{References}

Arfi R., Gurial D. and Bouvy M. (1993). Wind-induced resuspension in a shallow tropical lagoon. Estar. Coast. Shelf Sci. 36: 587-604.

Amatekpor J. K. (1989). The effects of seasonal flooding on the clay mineralogy of a soil series in the Volta Lake draw down area. Land Degradation and Rehabilitation 2: 89-100.

Amatekpor J. K. (1995). Soils of the Volta Lake draw down area and their suitability for aquaculture. Legon Agric. Res. Ext. J. 4: 87-96.

Anonymous (2004). Monitoring the white death-soil salinity. Nva Science in the news. Australian Academy of Sciences. http//www.science.org.au./nova/032/032print.htm

Anonymous (1998). Ramsar Library: The Directory of Wetlands of International Importance. www.ghanaweb.com.

Asiamah R. D. (1984). Report on Detailed Soil Survey. Angaw River Basin Irrigation Project, Volta Region. Ghana Libya African Arab Company, Sogakope, Ghana. 11-24. 
Asiamah R. D. (1995). Soils of Ho-Keta Plains, Volta Region, Ghana. Memoir No. 10. Soil Research Institute. Advent Press, Osu, Ghana, 13-28.

Bear F. E. and Toth S. J. (1948). Influence of calcium on availability of other soil cations. Soil Sci. 65: 67-74.

Brammer H. (1956). C. F. Charter's Interim Scheme for the classification of tropical soils. Soil and Land Use Survey Division, Ministry of Agriculture. Paper 2. Kumasi, Ghana. pp. 5-22.

Brammer H. (1962). Soils of Ghana. In Agriculture and Land Use in Ghana. (Brian Wills, ed.), pp. 88-126. London, Oxford University Press.

Brammer H. (1967). Soils of Accra Plains. Memoir No. 3. Soil Research Institute, Kumasi. State Publishing Corporation, Accra-Tema, Ghana. pp. 109-120.

Bremner J. M. (1996). Total Nitrogen. In Methods of soil analysis. Part 3 - Chemical methods. (D. L. Sparks, ed.), pp. 1065-1121. Soil Science Society of America Book Series, Madison, USA.

Brady N. C. (1990). The Nature and Properties of Soils, 10th edn. Collier Macmillan Publishers, London, UK. pp. 83-97.

Bray R. E. and Kutz L. T. (1945). Determination of total organic and available phosphorus in soils. Soil Sci. 59: 39-45.

Cline M. G. (1961). The changing model of soil. Proc Soil Sci. Soc. Am. 25: 442-445.

Coleman N. T. and Thomas, G. W. (1967). The basic chemistry of soil acidity. In Soil Acidity and Liming (R. W. Pearson and F. Adams, ed.), pp. 1-41. Agron. Monograph No. 12. Madison, Wisconsin, ASA.

Dorgbetor W. H. K., Amatekpor J. K. and Dowuona G. N. (1999). Pedological differences in a cambisol in the lower Volta floodplain of Ghana. Proceedings of the 16 th Annual General Meeting of the Soil Science Society of Ghana. pp. 27-39.

Eckert D. J. (1987). Soil test interpretation: Basic cation saturation ratios and sufficiency levels. In Soil testing: Sampling, correlation, calibration and interpretation. (J. R. Brown, ed.), pp. 53-64. SSSA Special Publication No. 21, Soil Science Soc. Am.

FAO (1988). Salt-affected soils and their management. FAO Soils Bull. 39. FAO, Rome, Italy. $131 \mathrm{pp.}$

FAO (1990). Guidelines for soil profile description, 3rd edn. FAO, Rome, Italy. 140 pp.

Frenkel H., Goertzen J. O. and Rhoades J. D. (1978). Effects of clay type and content, exchangeable sodium percentage and electrolyte concentration on clay dispersion and soil conductivity. Soil Sci. Soc. Am, J. 142: 32-39.

Gee G. W. and Bauder J. W. (1986). Particle size analysis. In Methods of Soil Analysis. (A. Klute et al., ed.), pp. 24-37. American Society of Agronomists.

Graham E. R. (1959). An explanation of theory and methods of soil testing. Missouri agric. Exp. St. Bull. 734.

Gyori D., Kisfalusi F. and Palkovics M. (1985). The influence of acidity on soil fertility. Agrokem. Talajt. 34: 73-76.

Islam M. Z. (1993). Leaching effect of saline drainage water on exchangeable cations in soil. J. Irrig. Engng rur. Plann. $24:$ 4-18.

ISSS/ISRIC/FAO (1998). World Reference Base for Soil Resources. World Soil Reference Report No. 84. FAO, Rome. 91 pp.

Junner N. R. and Bates D. A. (1945). Report on the Geology and Hydrology of the Coastal Area East of the Akwapim Range. Gold Coast Geological Survey Department Memoir 7: 9-27.

More S. D. (1994). Effect of farm waste and organic manures on soil properties, nutrient availability and rice yield of rice-wheat grown on Sodic Vertisol. J. Indian Soc. Soil Sci. 42(2): 253-256.

Munns D. N. and Franco A. A. (1982). Soil constraints on legume production. In Biological Nitrogen Fixation Technology for Tropical Agriculture (P. Graham and S. C. Harris, ed.), pp. 133-152. CIAT, California.

Nye P. H., Craig D. Coleman N. T. and J. L. Ragland (1961). Ion-exchange equilibrium involving aluminium. Proc. Soil Sci. Am. 25: 1417.

Kamprath, E. T. (1967). Soil acidity and response to liming. Tech. Bull. 4. Raleigh: Intern. Soil Testing Series, Soil Sci. Dept., N. C. State Univ. pp. 8-25.

MacDonald and Partners (1987). Supplementary Soil Survey for Kpong Irrigation Project. Soil Research Institute, Kumasi. pp. 5-18.

Morin, J., Benyamini Y. and Michaeli A. (1981). The dynamics of soil crusting by rainfall impact and water movement in the soil profile. $J$. Hydrol. 52: 321-335.

Pearson K. E. (2004). The basic effects of salinity and sodicity effects on soil physical properties. Information highlight for the general public. http:// waterquality.Montana.edu/docs/methane/basics_highlight.shtml.

Nikiforrof C. C. (1953). Pedological criteria of climate change. In Climatic Change: Evidence, causes and effects (H. Shapley, ed.), pp. 189210. Cambridge, Harvard Univ. Press, Mass.

Sharma S. K. and Manchanda H. R. (1996). Influence of leaching with different amounts of water on desalinization and permeability behaviour of chloride and sulphate-dominated saline soils. Agric. Wat. Mgmt 31(3): 225-235.

Schofield R. K. (1949). Effect of $p \mathrm{H}$ on electric charges carried by clay particle. J. Soil Sci.1: 1-8.

Siderius W. (1992). Soil derived land qualities SOL. 48. Soil Science Division, Department of Land Resources and Urban Science, International Institute of Aerospace Survey and Earth Sciences, The Netherlands. pp. 37-84.

Srivastava A . K. and Srivastava O. P. (1994). Gypsum requirement in relation to sodicity indices in a Typic Natraqualf. J. Indian Soc. Soil Sci. 42(1): 161-163.

Sun D. and Dickinson G. R. (1995). Salinity effects on tree growth, root distribution and transpiration of Casuarina cunninghamiana and Eucalyptus camaldulensis planted on a saline site in tropical north Australia. For. Ecol. Mgmt 77(1/3): 127-138.

Tamakloe E. K. (1966). Geomorphology of Keta Lagoon and its Environs. (BA Dissertation). University of Ghana.

Thomas G. W. and Swoboda A. R. (1963). Cation exchange in kaolinite-iron oxide systems. In Clays and Clay Minerals (W. F. Brindley, ed.), pp. 321-326. Macmillan Co., New York. 
Thomas G. W. (1982). Exchangeable cations. In Methods of Soil Analysis, Part 2. Chemical and Microbiological Methods (A. L. Page, ed.), pp. 159-166. Agron. Monograph No. 9 (2). ASA-SSSA, Madison, Wisconsin.

U. S. Salinity Laboratory Staff (1954). Diagnosis and improvement of saline and alkali soils. (L. A. Richards, ed.). U. S. Dept. of Agric. Handbook 60. U.S. Govt. Print Office, Washngton, DC.

van Doren D. M. and Tiplett G. B. (1979). Tillage systems for optimizing crop production. In Soil tillage and crop production. (R. Lal, ed.), pp. 2-23. IITA Proceeding 2. IITA, Ibadan, Nigeria.

van de Graaff, R. and R. Patterson (2001). Explaining the mysteries of salinity, SAR and ESP in on-site practice. http://www.launionsweb.org/salinity.htm.

Walkley A. and Black I. A. (1934). An examination of the method for determining soil organic matter and proposed modification of the chromic acid titration method. Soil Sci. 37: 29-38. 